University of Texas Rio Grande Valley

ScholarWorks @ UTRGV

Anthropology Faculty Publications and

Presentations

$6-2020$

\title{
Buen Suceso: A New Multicomponent Valdivia Site in Santa Elena, Ecuador
}

Sarah M. Rowe

The University of Texas Rio Grande Valley, sarah.rowe@utrgv.edu

Guy S. Duke

The University of Texas Rio Grande Valley, guy.duke@utrgv.edu

Follow this and additional works at: https://scholarworks.utrgv.edu/anthro_fac

Part of the Anthropology Commons

\section{Recommended Citation}

Rowe, S. M., \& Duke, G. S. (2020). Buen Suceso: A New Multicomponent Valdivia Site in Santa Elena, Ecuador. Latin American Antiquity, 31(3), 639-645. https://doi.org/10.1017/laq.2020.43

This Article is brought to you for free and open access by the College of Liberal Arts at ScholarWorks @ UTRGV. It has been accepted for inclusion in Anthropology Faculty Publications and Presentations by an authorized administrator of ScholarWorks @ UTRGV. For more information, please contact justin.white@utrgv.edu, william.flores01@utrgv.edu. 


\title{
Buen Suceso: A New Multicomponent Valdivia Site in Santa Elena, Ecuador
}

\author{
Sarah M. Rowe (iD) and Guy S. Duke
}

\begin{abstract}
New radiocarbon dates and excavations show that Buen Suceso (OSE-M-2M-4) in Santa Elena, Ecuador, was occupied between 3700 and 1425 BC. These dates demonstrate that Buen Suceso is a rare multicomponent Valdivia site and one of the longer-occupied Valdivia sites investigated to date.
\end{abstract}

Keywords: Valdivia, Formative period, radiocarbon dates, Ecuador

Nuevas excavaciones y fechados radiocarbónicos demuestran que Buen Suceso (OSE-M-2M-4; Santa Elena, Ecuador) estuvo habitado entre 3700 y 1425 aC (Valdivia, fase Ib a fase VIIIb). Estas fechas señalan que se trata de un sitio Valdivia multicomponente excepcional y uno de los habitado por más tiempo, entro los sitios Valdivia investigados hasta la fecha. El diseño circular del sitio sugiere procesos sociales muy diferentes a los del sitio contemporáneo Real Alto (OGCh-12). Futuras comparaciones entre ambos sitios podrían revelar de manera fructífera la variación social en esta cultura formativa.

Palabras clave: Valdivia, periodo Formativo, fechados radiocarbónicos, Ecuador

$\mathrm{T}$ he Valdivia culture (4400-1450 BC) corresponds to the Early Formative period of prehispanic Ecuador, with sites found across much of the western lowlands of the country (Supplemental Figure 1). Valdivia is characterized by one of the earliest ceramic traditions in the Americas (Hill 1972-1974; Meggers et al. 1965), the beginning of sedentary village life in the region (Lathrap et al. 1977), and the cultivation of domesticated plants (e.g., Pearsall 2008).

Since excavation of the Valdivia type-site (G-31) in the 1950s (Meggers et al. 1965), archaeologists have sought to clarify the temporal extent and identify social changes within the Valdivia tradition (for detailed discussion of the Valdivia absolute chronology, see Marcos 2008; Marcos and Michczynski 1996; Marcos and Obelic 1998; Tabarev et al. 2016; and Zeidler 2003). The current chronology divides 11 phases into four periods: early, middle, late, and terminal (Supplemental Table 1). Most investigated sites were occupied for only one or two phases, which makes it difficult to distinguish regional differences from temporal change. The main exception to this is the Real Alto site (OGCh-12) on the semiarid Santa Elena Peninsula, which was occupied nearly the entirety of the Valdivia tradition. Here, changes to site layout, ritual and burial practices, expanded trade networks, and associated settlement patterns beginning in Middle Valdivia all suggest the development of incipient hierarchies in the region and in the Valdivia tradition more broadly (Damp 1984; Lathrap et al. 1977; Marcos 1978; Zeidler 1984). Nevertheless, it remains unclear whether these social changes are representative of the whole of the Valdivia tradition and territorial expanse.

\section{Buen Suceso Excavations}

Buen Suceso (OSE-M-2M-4) lies $9 \mathrm{~km}$ inland along the Manglaralto Valley in the Santa Elena Province of coastal Ecuador, on the flanks of the Chongon-Colonche hills. Local

Sarah M. Rowe (sarah.rowe@utrgv.edu, corresponding author) and Guy S. Duke — Department of Anthropology, University of Texas Rio Grande Valley, 1201 W. University Drive, Edinburg, Texas 78539, USA

Latin American Antiquity, pp. 1-7

Copyright (C) 2020 by the Society for American Archaeology

doi:10.1017/laq.2020.43 
ecozones within a day's walk of the site include the maritime and littoral resources of the equatorial Pacific coast, such as mangrove swamps, as well as dry scrublands and tropical cloud forests. Average annual rainfall in the area is $530 \mathrm{~mm}$, approximately twice that received on the Santa Elena Peninsula (Amado Garzaro 1990).

Buen Suceso is approximately $12 \mathrm{~km}$ north of the site of Loma Alta (OGSEMa-182; Norton 1982; Stahl 1984) via a modern footpath that crosses the intervalley hills. The Valdivia typesite is approximately $20 \mathrm{~km}$ away, following a path to the mouth of the valley and then continuing southward along the coast to the mouth of the Valdivia River. The proximity of these sites is such that their inhabitants could have been in semifrequent contact. Real Alto is located approximately $70 \mathrm{~km}$ to the south, in the Chanduy River drainage, and would have involved two or more days of travel to reach. It was thus likely part of the interaction zone for people at Buen Suceso but for more occasional interactions.

Buen Suceso measures $130 \times 100 \mathrm{~m}$ and is characterized by a raised circular-shaped midden surrounding a cleared plaza area (Supplemental Figure 2). This spatial layout is characteristic of Early Valdivia sites (Raymond 2003). At Buen Suceso this spatial organization seems to have persisted throughout the 2,300-year occupation of the site presented here. The site is situated in a farmed field located on the lands of the comuna Dos Mangas. A modern dirt road cuts the western edge of the site, and the southern arm of the village midden is partially eroded by the Río Culebra, a tributary of the Manglaralto River.

Excavations in 2009 and 2017 (Rowe 2014, 2016, 2018; Rowe and Duke 2018, 2019) recovered portions of three structures and numerous midden deposits that provide radiocarbon and ceramic evidence for Valdivia occupation of the site beginning around 3700 BC (Early Valdivia Phase Ib) and ending around $1425 \mathrm{BC}$ (Terminal Valdivia Phase VIIIb). Together, these contexts indicate that Buen Suceso was a rare, multicomponent Valdivia site and is among the longest-occupied Valdivia sites investigated to date.

\section{${ }^{14} \mathrm{C}$ Contexts}

The earliest dates at Buen Suceso come from excavation units on the northern arm of the midden ring surrounding the site, specifically from Units 5 and 6 excavated during the 2017 excavations (Table 1). Two carbon samples were tested from Unit 6: one each from Level 4 and Level 5 (Figure 1). The Level 4 sample (UCIAMS \#211882) was recovered $60 \mathrm{~cm}$ below the surface from a brownish-yellow silty-loam midden matrix. The sample dated to the Early Valdivia period (Phase $\mathrm{Ib}, 3703-3637 \mathrm{cal} \mathrm{BC}$ ). Level 4 contained two figurines (one stone and one ceramic), a piece of spondylus shell (genus Spondylus), and numerous ceramic and lithic items (Supplemental Figure 3). The Level 5 sample (UCIAMS \#211885) was recovered $97 \mathrm{~cm}$ below the surface from a gray silty-ash matrix containing roots and stones. Its date is later than the sample from Level 4 (Early Valdivia, Phase IIa/IIb, 3265-2920 cal BC), although it is possible that it is actually associated with the large feature of dark gray soil associated with Level 4 . The differentiation between this feature and Level 5 was indistinct during excavation.

Two carbon samples were recovered from Unit 5: one from Level 3 and another from Level 5 (Figure 2). The Level 3 sample dated to the Early Valdivia period (UCIAMS \#211883; Phase IIa/IIb, 3093-2922 cal BC). It was recovered $58 \mathrm{~cm}$ below the surface in a grayish-brown silty-ash matrix. The sample from Level 5 (UCIAMS \#211879) was recovered $77 \mathrm{~cm}$ below the surface from a chalky (caliche) floor and dated to the Early Valdivia period (Phase Ib/IIa, 3335-3016 cal BC). This may be the floor of a domestic structure.

Evidence for Middle Valdivia occupation of Buen Suceso comes from two locations. First, in Unit 3 (Figure 1) a sample was recovered from Level 4, a cobble floor $61 \mathrm{~cm}$ below the surface (UCIAMS \#211877). This level includes the subfloor materials of coffee-colored silty loam mixed with small stones. This cobble floor likely represents a domestic structure. This sample dated to the Middle Valdivia period (Phase IIb/ III, 2838-2488 cal BC).

The second location that exhibits evidence of Middle Valdivia occupation is a large cobble floor located near the center of the site, Structure 
Table 1. Radiocarbon Dates from Buen Suceso.

\begin{tabular}{|c|c|c|c|c|c|}
\hline Reference, Lab \# & $\begin{array}{l}{ }^{14} \mathrm{C} \pm \sigma \text { Yrs BP } \\
\delta^{13} \mathrm{C} \text {-corrected }\end{array}$ & $\mathrm{cal} \mathrm{BC} \mathrm{Yrs} \pm 2 \sigma$ & Context & Description & $\begin{array}{c}\text { Valdivia Phase } \\
\text { and Period }\end{array}$ \\
\hline UCIAMS \#211883 & $4440 \pm 15$ & $\begin{array}{c}\mathbf{3 0 9 3 - 2 9 2 2} \\
3093-2922 \\
(95.4 \%)\end{array}$ & $\begin{array}{l}\text { OSE-M-2M-4 2017, } \\
\text { Unidad 5, Nivel } 3\end{array}$ & Midden deposit & IIa/IIb - Early \\
\hline UCIAMS \#211879 & $4495 \pm 15$ & $\begin{array}{c}\mathbf{3 3 3 5}-\mathbf{3 0 1 6} \\
3335-3212 \\
(43.7 \%) \\
3192-3152(7.6 \%) \\
3137-3016 \\
(44.1 \%)\end{array}$ & $\begin{array}{l}\text { OSE-M-2M-4 2017, } \\
\text { Unidad 5, Nivel } 5\end{array}$ & Caliche floor & Ib/IIa - Early \\
\hline UCIAMS \#211882 & $4915 \pm 15$ & $\begin{array}{c}\mathbf{3 7 0 3}-\mathbf{3 6 3 7} \\
3703-3637 \\
(95.4 \%)\end{array}$ & $\begin{array}{l}\text { OSE-M-2M 2017, } \\
\text { Unidad 6, Nivel } 4\end{array}$ & Midden deposit & Ib - Early \\
\hline UCIAMS \#211885 & $4455 \pm 15$ & $\begin{array}{c}\mathbf{3 2 6 5}-\mathbf{2 9 2 0} \\
3265-3243(3.7 \%) \\
3104-2920 \\
(91.7 \%)\end{array}$ & $\begin{array}{l}\text { OSE-M-2M-4 2017, } \\
\text { Unidad 6, Nivel } 5\end{array}$ & $\begin{array}{c}\text { Sample likely came } \\
\text { from Nivel } 4 \text { Rasgo 2, a } \\
\text { poorly defined } \\
\text { intrusive feature }\end{array}$ & $\mathrm{IIa} / \mathrm{IIb}$ - Early \\
\hline UCIAMS \#211876 & $4130 \pm 15$ & $\begin{array}{c}\mathbf{2 8 5 7 - 2 5 0 0} \\
2857-2811 \\
(18.0 \%) \\
2748-2724(4.2 \%) \\
2699-2568 \\
(69.9 \%) \\
2516-2500(3.3 \%)\end{array}$ & $\begin{array}{c}\text { OSE-M-2M-4 2017, } \\
\text { Unidad 2, Nivel 3, } \\
\text { Rasgo } 1\end{array}$ & $\begin{array}{c}\text { Base of posthole in } \\
\text { cobble floor, Structure } \\
1\end{array}$ & IIb/III - Middle \\
\hline ISGS \#A1957 & $4190 \pm 25$ & $\begin{array}{c}\mathbf{2 8 7 7 - 2 6 2 2} \\
2877-2622 \\
(95.4 \%)\end{array}$ & $\begin{array}{l}\text { OSE-M-2M-4 2009, } \\
\text { Sector C N1/2 O30, } \\
\text { Nivel } 4\end{array}$ & $\begin{array}{l}\text { Dedicatory deposit } \\
\text { under cobble floor, } \\
\text { Structure } 1\end{array}$ & IIb/III - Middle \\
\hline UCIAMS \#211884 & $3250 \pm 15$ & $\begin{array}{c}\mathbf{1 5 2 7 - 1 4 2 6} \\
1527-1426 \\
(95.4 \%)\end{array}$ & $\begin{array}{l}\text { OSE-M-2M-4 2017, } \\
\text { Unidad 3, Nivel } 3\end{array}$ & Midden deposit & $\begin{array}{c}\text { VIIIb - } \\
\text { Terminal }\end{array}$ \\
\hline UCIAMS \#211877 & $4105 \pm 15$ & $\begin{array}{c}\mathbf{2 8 3 8}-\mathbf{2 4 8 8} \\
2838-2814(7.7 \%) \\
2675-2488 \\
(87.7 \%)\end{array}$ & $\begin{array}{l}\text { OSE-M-2M-4 2017, } \\
\text { Unidad } 3 \text { \& } 3 \\
\text { Expansion, Nivel } 4\end{array}$ & Cobble floor & IIb/III - Middle \\
\hline ISGS \#A1954 & $3665 \pm 20$ & $\begin{array}{c}\mathbf{2 1 2 0}-\mathbf{1 8 9 5} \\
2120-2096(4.7 \%) \\
2040-1895 \\
(90.7 \%)\end{array}$ & $\begin{array}{l}\text { OSE-M-2M-4 2009, } \\
\text { Sector A S2/3 O30/31 } \\
\text { Context } 15\end{array}$ & Midden deposit & V-VII - Late \\
\hline
\end{tabular}

Notes: All dates are derived from charcoal samples and have been corrected for isotopic fractionation by the respective laboratories: the University of California Irvine Keck Carbon Cycle AMS Facility (UCIAMS) and the Prairie Research Institute Division of the Illinois State Geologic Survey (ISGS). Calibrations calculated in OxCal v4.3.2 (Bronk Ramsey 2017) using the SHCal13 atmospheric curve (Hogg et al. 2013).

1, which immediately overlays sterile soil. Excavations in 2009 revealed a dedicatory deposit below the cobble floor (R1, Figure 1) consisting of two stacked and inverted vessel bases, a figurine fragment, and a charcoal sample (Supplemental Figure 4). This sample was dated to the Middle Valdivia period (ISGS \#A1957; Phase IIb/III, 2877-2622 cal BC). Excavations in 2017 confirmed the Middle Valdivia date of Structure 1. A radiocarbon sample taken from the base of a large posthole (R4, Figure 1), $40 \mathrm{~cm}$ below the surface (UCIAMS \#211876), was dated to the Middle Valdivia period (Phase IIb/III, 2857-2500 cal BC). There was no wall trench or enclosing postholes, so it was likely a prepared floor with no superstructure. Based on the size and position of this floor, we hypothesize that Structure 1 had a communal or ritual use.

The 2009 excavations included a 2 m deep unit in the south arm of the midden ring. A 

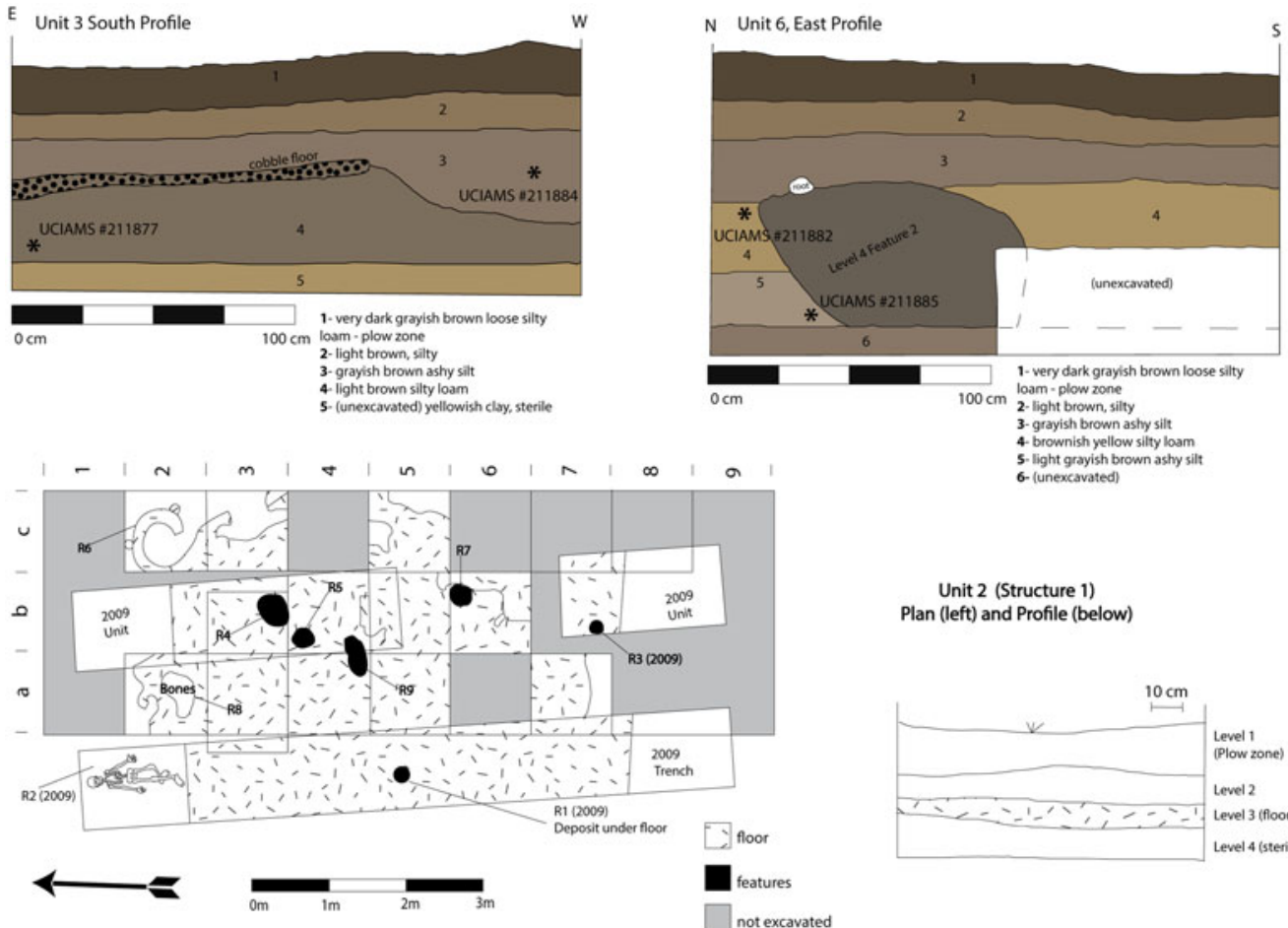

Unit 2 (Structure 1)

Plan (left) and Profile (below)

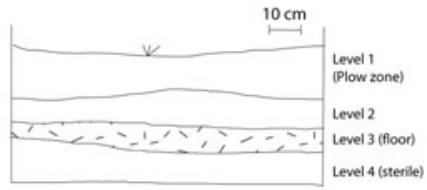

Figure 1. Unit 3 and Unit 6, 2017 excavation profiles. Structure 1 floor plan and profile. (Color online)
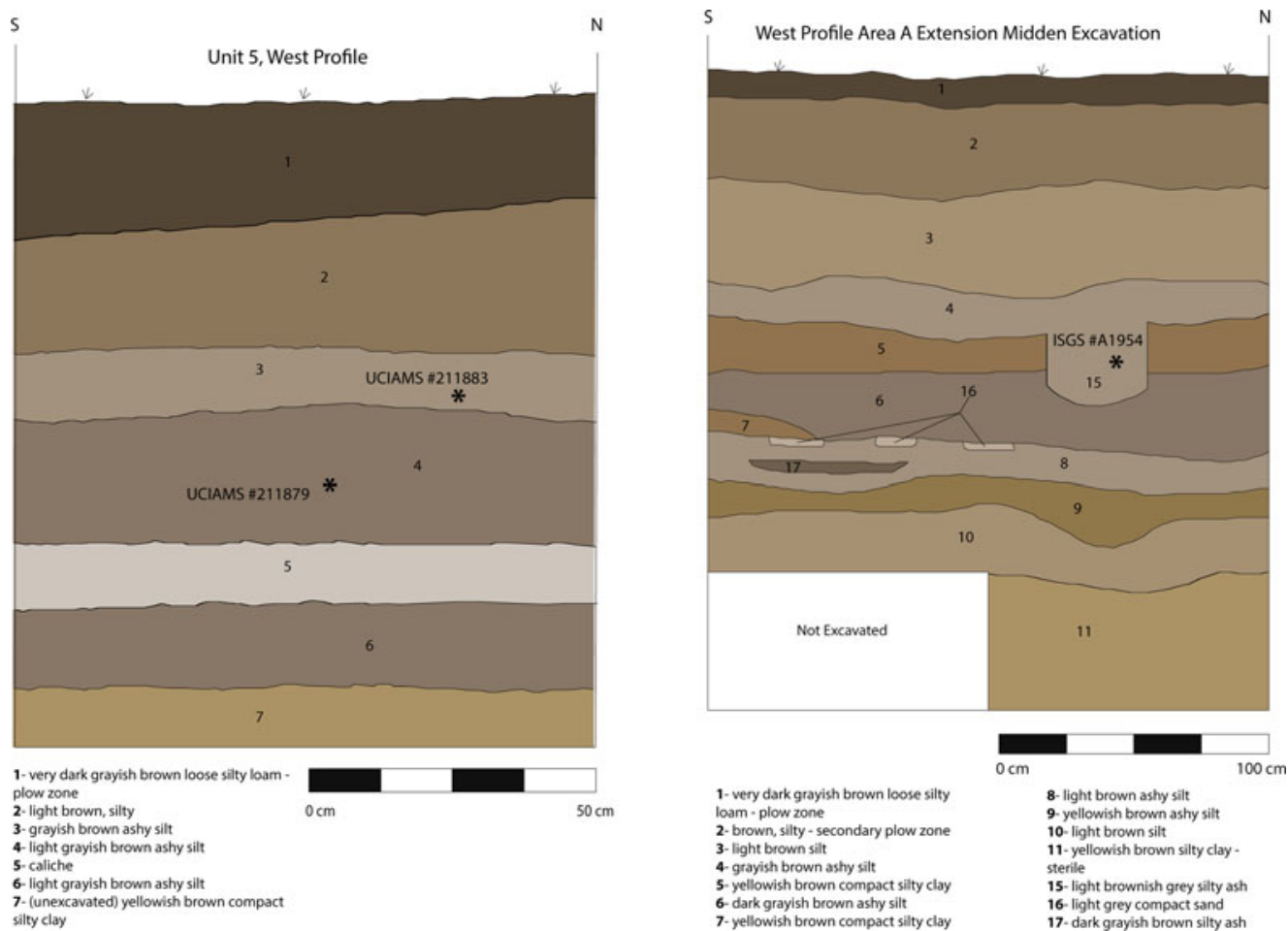

Figure 2. Unit 5, 2017, and 2009 midden excavation profiles. (Color online) 


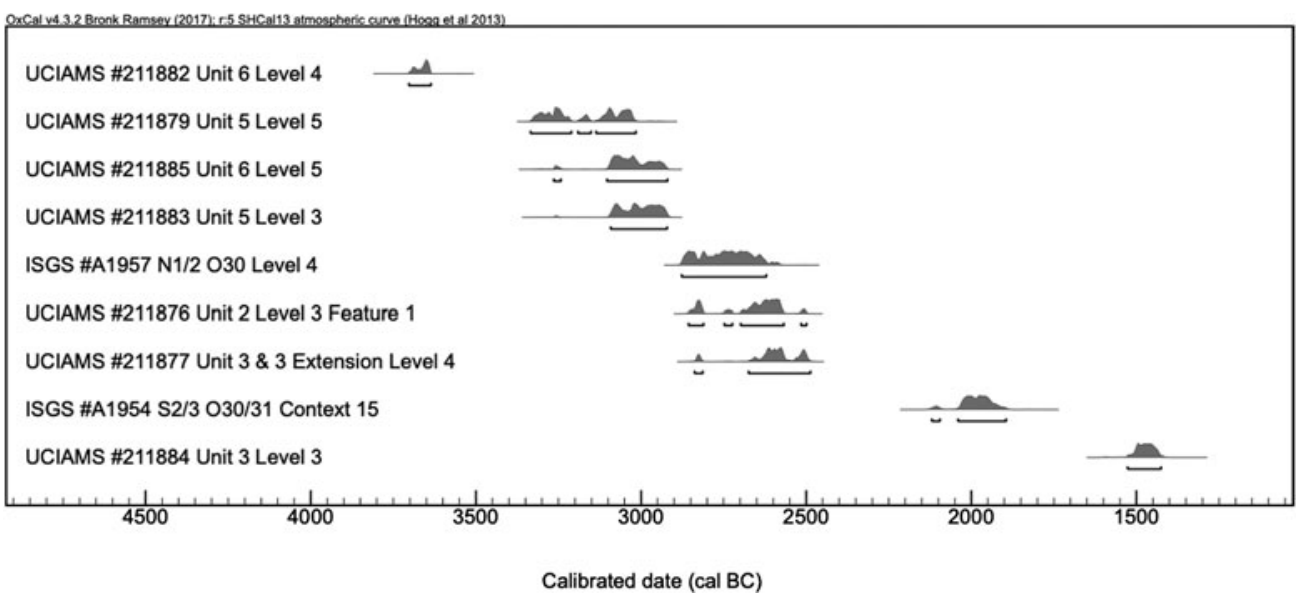

Figure 3. Radiocarbon calibration curves from Buen Suceso.

charcoal sample (ISGS \#A1954), dating to the Late Valdivia period (Phase V/VI/VII, 2120 1895 cal BC), was recovered at a depth of 110 $\mathrm{cm}$ below the surface from a pit feature dug at the interface of Layers 4 and 5 (context 15; Figure 2). This pit was filled with a grayish-brown silty ash and contained two ceramic sherds and a few lithic artifacts. This Late Valdivia date was further supported by the ceramics found in adjacent levels of the midden (Rowe 2014:354360).

Finally, the Unit 3, Level 3, sample (UCIAMS \#211884) was recovered $50 \mathrm{~cm}$ below the surface in a coffee-colored midden deposit above the level of the cobble floor (Level 4; Figure 1). This sample dated to the Terminal Valdivia period (Phase VIIIb, 15271426 cal BC). Terminal Valdivia occupation has not previously been identified on the central Ecuadorian coast. Although this is a midden layer and not a feature, it is possible that future excavations will recover evidence of the transition between Valdivia and the subsequent Machalilla tradition, for which there are a few sherds collected from the surface of the site.

\section{Discussion}

In summary, in our excavations at Buen Suceso we identified three floors and numerous midden deposits that demonstrate multicomponent Valdivia occupation at the site (Figure 3). The circular layout of Buen Suceso originated in Early
Valdivia and persisted through the life of the site. One caliche floor (in Unit 5) represents the Early Valdivia occupation. Two cobble floors (in Unit 3 and Structure 1) indicate Middle Valdivia occupation, whereas midden deposits provide evidence for all periods of occupation at the site. Further excavation is required to determine whether this occupation was continuous or episodic.

The only other investigated sites that approach or surpass the longevity of Buen Suceso are the Valdivia type-site and Real Alto. Due to the excavation methodology employed at the Valdivia type-site (Meggers et al. 1965), it cannot be used as a reliable source of comparative information regarding social processes in the past. Thus, the most fruitful comparisons for Buen Suceso are the ongoing excavations at Real Alto. A dramatic spatial reorganization occurred in the Middle Valdivia period at Real Alto as it transformed into a regional center. Buen Suceso, in contrast, exhibits a remarkable degree of continuity throughout the 2,300 years of Valdivia occupation. This suggests that very different processes were behind the ongoing occupations at the two sites and that the Valdivia culture was marked by greater social and regional variability than previously recognized. Future work at Buen Suceso will explore this variation.

Acknowledgments. The 2009 excavations were funded by a Scholar Award from the Philanthropic Educational Organization and a Dissertation Travel Grant from the Graduate College of the University of Illinois. The 2017 excavations 
were funded by a Fulbright Scholar Award. Permits for excavation and sample export were granted by the Instituto Nacional de Patrimonio Cultural, Guayaquil (011.SRL.INPC.2009; 007.DR5.INPC.2017), Ecuador.

Data Availability Statement. All primary data were generated by the coauthors. Data are maintained by the Proyecto Arqueológico Ríos Culebra-Colín, University of Texas Rio Grande Valley.

Supplemental Materials. For supplemental material accompanying this article, visit https://doi.org/10.1017/laq.2020.43.

Supplemental Figure 1: Map of coastal Ecuador with Valdivia sites mentioned in the text.

Supplemental Figure 2: Buen Suceso site map with excavation units.

Supplemental Figure 3: Associated artifacts, Unit 6, Level 4: (a) stone figurine; (b) ceramic figurine; (c) front and back of Spondylus fragment; (d) pie-crust rim; (e) cut and bevel rim.

Supplemental Figure 4: Dedicatory deposit under Structure 1: (a) outer vessel; (b) inner vessel; (c) figurine fragment.

Supplemental Table 1. Correlation of Relative and Absolute Chronologies for Valdivia by Phase (Zeidler 2003:519).

\section{References Cited}

Amado Garzaro, Juan Carlos

1990 Estudio Hidrogeológico de la Cuenca del Río Manglaralto, Provincia del Guayas. Licenciatura thesis, Facultad de Ingeniería en Ciencias de la Tierra, Escuela Superior Politécnica del Litoral, Guayaquil.

Bronk Ramsey, Christopher

2017 OxCal Program 4.3.2. Oxford Radiocarbon Accelerator Unit, Oxford University.

Damp, Jonathan E.

1984 Environmental Variation, Agriculture, and Settlement Processes in Coastal Ecuador (3300-1500 BC). Current Anthropology 25:106-111.

Hill, Betsy D.

1972-1974 A New Chronology of the Valdivia Ceramic Complex from the Coastal Zone of Guayas Province, Ecuador. Nawpa Pacha 10/12:1-32.

Hogg, Alan G., Guan Hua, Paul G. Blackwell, Mu Niu, Caitlin E. Buck, Thomas P. Guilderson, Timothy J. Heaton, Jonathan G. Palmer, Paula J. Reimer, Ron W. Reimer, Christian S. M. Turney, and Susan R. H. Zimmerman

2013 SHCal13 Southern Hemisphere Calibration, 0-50,000 Years cal BP. Radiocarbon 55:1889-1903.

Lathrap, Donald W., Jorge G. Marcos, and James A. Zeidler

1977 Real Alto: An Ancient Ceremonial Center. Archaeology 30(1):2-13.

Marcos, Jorge G.

1978 The Ceremonial Precinct of Real Alto: Organization of Time and Space in Valdivia Society. PhD dissertation, Department of Anthropology, University of Illinois, Urbana.

2008 La Cronología e Investigación de la Cerámica Valdivia a los 50 años de su Descubrimiento. Miscelánea Antropológica Ecuatoriana: Segunda Época 1(1):66-101.
Marcos, Jorge G., and Adam Michczynski

1996 Good Dates and Bad Dates in Ecuador: Radiocarbon Samples and Archaeological Excavation: A Commentary Based on the Valdivia Absolute Chronology. Andes: Boletín de la Misión Arqueológica Andina 1:93-113.

Marcos, Jorge G., and Bogomil Obelic

$1998{ }^{14} \mathrm{C}$ and TL Chronology for the Ecuadorian Formative. In El área septentrional andina: Arqueología y etnohistoria, edited by Mercedes Guinea, Jorge G. Marcos, and Jean-François Bouchard, pp. 347-359. Ediciones Abya-Yala, Quito.

Meggers, Betty J., Clifford Evans, and Emilio Estrada 1965 Early Formative Period of Coastal Ecuador: The Valdivia and Machalilla Phases. Smithsonian Contributions to Anthropology 1. Smithsonian Institution, Washington, DC.

Norton, Presley

1982 Preliminary Observations on Loma Alta, an Early Valdivia Midden in Guayas Province, Ecuador. In Primer simposio de correlaciones antropológicas AndinoMesoamericano, edited by Jorge G. Marcos and Presley Norton, pp. 102-119. Escuela Superior Politécnica del Litoral, Guayaquil, Ecuador.

Pearsall, Deborah M.

2008 Plant Domestication and the Shift to Agriculture in the Andes. In The Handbook of South American Archaeology, edited by Helaine Silverman and William H. Isbell, pp. 105-120. Springer, New York.

Raymond, J. Scott

2003 Social Formations in the Western Lowlands of Ecuador during the Formative Period. In Archaeology of Formative Ecuador, edited by J. Scott Raymond and Richard L. Burger, pp. 33-67. Dumbarton Oaks, Washington, DC.

Rowe, Sarah M.

2014 Community and Memory at the Late Valdivia Site of Buen Suceso, Ecuador. PhD dissertation, Department of Anthropology, University of Illinois, Urbana.

2016 Ceramic Variation and Negotiated Communities in the Late Valdivia Phase of Coastal Ecuador. Journal of Anthropological Archaeology 49:63-82.

2018 La Memoria contra la Jerarquía: Excavaciones en Buen Suceso. In De arqueología hablamos las mujeres: Perspectivas sobre el pasado ecuatoriano, edited by María. A. Cordero, pp. 63-79. Universidad Laica Eloy Alfaro de Manabí, Manta, Ecuador.

Rowe, Sarah M., and Guy S. Duke

2018 Informe preliminar, investigación arqueológica: Sitio Buen Suceso, Comuna Dos Mangas, Provincia de Santa Elena. Report submitted to Instituto Nacional de Patrimonio Cultural, Región 5. Guayaquil, Ecuador.

2019 Informe complementario, investigación arqueológica: Sitio Buen Suceso, Comuna Dos Mangas, Provincia de Santa Elena. Report submitted to Instituto Nacional de Patrimonio Cultural, Región 5. Guayaquil, Ecuador.

Stahl, Peter W.

1984 Tropical Forest Cosmology: The Cultural Context of the Early Valdivia Occupations at Loma Alta (Ecuador). $\mathrm{PhD}$ dissertation, Department of Anthropology, University of Illinois, Urbana.

Tabarev, Andrey V., Yoshitaka Kanomata, Jorge G. Marcos, Alexander N. Popov, and Boris V. Lazin

2016 Insights into the Earliest Formative Period of Coastal Ecuador: New Evidence and Radiocarbon Dates from the Real Alto Site. Radiocarbon 58:323-330. 
Zeidler, James A.

1984 Social Space in Valdivia Society: Community Patterning and Domestic Structure at Real Alto, 30002000 B.C. PhD dissertation, Department of Anthropology, University of Illinois, Urbana. University Microfilms, Ann Arbor.

2003 Appendix A: Formative Period Chronology for the Coast and Western Lowlands of Ecuador. In
Archaeology of Formative Ecuador, edited by J. Scott Raymond and Richard L. Burger, pp. 487-527. Dumbarton Oaks, Washington, DC.

Submitted March 21, 2019; Revised December 18, 2019;

Accepted February 20, 2020 